\title{
Research and development from the bottom up - introduction of terminologies for new product development in emerging markets
}

\author{
Alexander Brem ${ }^{*}$ and Pierre Wolfram
}

\author{
* Correspondence: \\ brem@idee-innovation.de \\ School of Business and Economics, \\ Friedrich-Alexander-Universität \\ Erlangen-Nürnberg, Findelgasse 7-9, \\ Nuremberg 90402, Germany
}

\begin{abstract}
This paper gives a comprehensive overview of the commonly used terms jugaad, frugal innovation, frugal engineering, constraint-based innovation, Gandhian innovation, catalytic innovation, grassroots innovation, indigenous innovation, and reverse innovation. Based on that, a conceptual framework is introduced consisting of three core dimensions: sophistication, sustainability, and emerging market orientation. On the basis of these dimensions, analogies and distinctions between the terms are identified and general tendencies are explored such as the increasing importance of sustainability in social and ecological context or the growing interest of developed market firms in approaches from emerging markets. Hence, the presented framework supports further research in new paradigms for research and development (R\&D) in developed market firms (DMFs), particularly in relation to emerging markets. This framework enables scholars to compare concepts from developed and emerging markets, to address studies specifically by using consistent terms, and to advance research into the concepts according their characterization.
\end{abstract}

Keywords: Frugal innovation; Reverse innovation; Emerging economies; DMFs; R\&D

\section{Background}

In the current phase of globalization, emerging market firms (EMFs) have begun to catch up with those from developed economies in terms of developing innovative capabilities (Jiatao and Rajiv 2009). Western companies entered emerging markets thinking they could simply harvest the fruits of research and development (R\&D) and innovation skills painstakingly developed in their home countries (Brown and Hagel 2005). However, while there are several examples of successful technology transfers from Europe to Asia, there have been several unsuccessful attempts as well (Brem and Moitra 2011). Western companies are now encountering a reverse effect of their investments in developing countries because of the exponential growth of those markets. Over the last decade, these countries $^{\mathrm{a}}$ generated an average growth rate of about $4.5 \%$, despite the global financial crisis. Whereas countries with a developed economy ${ }^{\mathrm{b}}$ achieved a growth rate lower than $2 \%$ (International Monetary Fund 2012). A survey of 547 executives worldwide carried out by Ernst \& Young shows that the number of middle-income customers is expected to increase by three billion by 2030 , denoting a rise in demand of goods from US $\$ 21$ trillion to US\$56 trillion - with focus on emerging countries (Ernst \& Young 2011).

C 2014 Brem and Wolfram; licensee Springer. This is an Open Access article distributed under the terms of the Creative Commons Attribution License (http://creativecommons.org/licenses/by/2.0), which permits unrestricted use, distribution, and reproduction in any medium, provided the original work is properly credited. 
In this context, it is not surprising that, when surveyed, developed market firms (DMFs) said their preferred prospective international R\&D locations are China (62\%), the USA (41\%), and India (29\%) (UNCTAD 2005). However, developing products in and for resource-constraint markets is far different from product development in Western countries. It means for Western companies to unlearn traditional R\&D approaches including the reduction of many complex and resource intensive steps (Ray and Ray 2010; London and Hart 2004). The ability of integration technologies and knowledge developed in local institutions may be the enabler to serve customer needs in mass markets (Almeida and Phene 2004). Some multinational companies succeed already by even bringing innovations from developing countries in the West. General Electric, as a well-known example, has launched a cheap ultrasound device originally developed for the Chinese market. It has become the basis of a global business with eager customers in both developed and developing countries. This trend is apparent in consumer goods as well. Other examples from the healthcare or telecommunication sector are also based on frugal principles. For instance, Ray and Ray (2010) present a case study about C-Dot (indigenous enterprise of the governmental Department of Telecommunications in India) which is the enabler of telecommunications in rural regions by developing a simple and affordable switching technology called RAX (R\&D costs about $\$ 36$ million instead of $\$ 1,400$ million). Hereby, C-Dot focused on frugality, local requirements, integrated local talents, and local partners to establish an ecosystem.

Hence, innovation, an often investigated research topic among organizational theory researchers (Brem 2011), is increasingly shifting to emerging markets (Petrick 2011). The tendency of the growing importance of emerging markets and the awareness concerning innovation for economic success are reflected in the dramatic increase of articles in the press about innovation in combination with emerging markets (e.g., Reena 2009; Saraf 2009; Govindarajan and Trimble 2005; Christensen et al. 2004).

Considering science, however, academic papers are rare which investigate innovations in/from emerging markets. Though, the new approaches from emerging markets are able to contribute remarkably to theory, i.e., to the resource-based view (RBV). Amit and Schoemaker (1993), for instance, divide the RBV into resources and necessary capabilities where resources are the 'stock of available factors' and capabilities are the 'capacity to deploy resources [...] using organizational processes, to effect a desired end' (p. 35). Companies within emerging markets face strong constraints of resources and develop capabilities to create valuable product solutions by replacing elements of capital with local labor at low costs (Ray and Ray 2010; Dawar and Chattopadhyay 2002). Such capabilities are worthy for further investigation since increasing scarcity of resources came into focus in developed markets, too. The innovative concepts from emerging markets need to be considered and understood.

However, by reading articles regarding innovative approaches from emerging markets, it is conspicuous that there is no common understanding of used terms and the relations between the approaches. The different terms are partly confusing, and no delineation between the terms is made. That hinders the desired academic discussion gaining deeper insights from different perspectives. Therefore, a common understanding of these terms is a prerequisite for further research and a foundation for exchanging ideas and building knowledge (Suddaby 2010). Hence, the following research question is asked: What are applicable characteristics to delineate the terms from emerging markets? 
This study provides a brief overview of the terms and descriptions currently used in press and academic literature plus a clear delineation of the terms. Hereby, the specific attributes of the terms are identified and consolidated. Subsequently, the consolidated attributes serve as measurement where the terms can be aligned to. In this vein, the linkages and relationships between the terms and their underlying concepts are uncovered. In the last step, a conceptual framework is introduced to classify the terms in several dimensions.

\section{Literature review of relevant NPD terms from emerging markets}

To identify concepts for gaining innovative solutions for and in emerging markets, an investigation is carried out by scanning the databases Google Scholar and Business Source Complete (BSC). BSC includes 20 databases such as EBSCO Host, Econ Lit, and LISTA covering articles from more than 1,200 journals, going back to 1886 (Business Source Complete 2013). In the first step, we start to screen the databases for the most famous terms 'frugal innovation' and 'reverse innovation' in BSC and Google Scholar. All the results were adjusted by eliminating doublings and book overviews.

Thereby, only 43 results are listed in the search of frugal innovation and 98 in reverse innovation. By dint of these $141(43+98)$ articles, we identified related concepts mentioned within these papers. Hereby, terms are only further considered if they possess a clear relationship to the emerging market context and frugal or reverse innovation, as well as emerge at least in three of investigated papers. All identified terms are presented in Figure 1.

As a next step, the databases were screened regarding all identified terms from the last step. Hereby, 363 papers were explored including 119 academic articles (see Table 1). First, the academic articles were used to comprehensively describe the terms. However, it was notable that a lot of academic articles only mention the terms without explaining them in depth but referring to press articles respectively practice-oriented publications (i.e. Harvard Business Review). Accordingly, the literature focus was extended to all identified papers in BSC and Google Scholar to get a comprehensive and detailed overview of all identified terms.

In the context of innovation from emerging markets, the abovementioned terms are presented in detail.

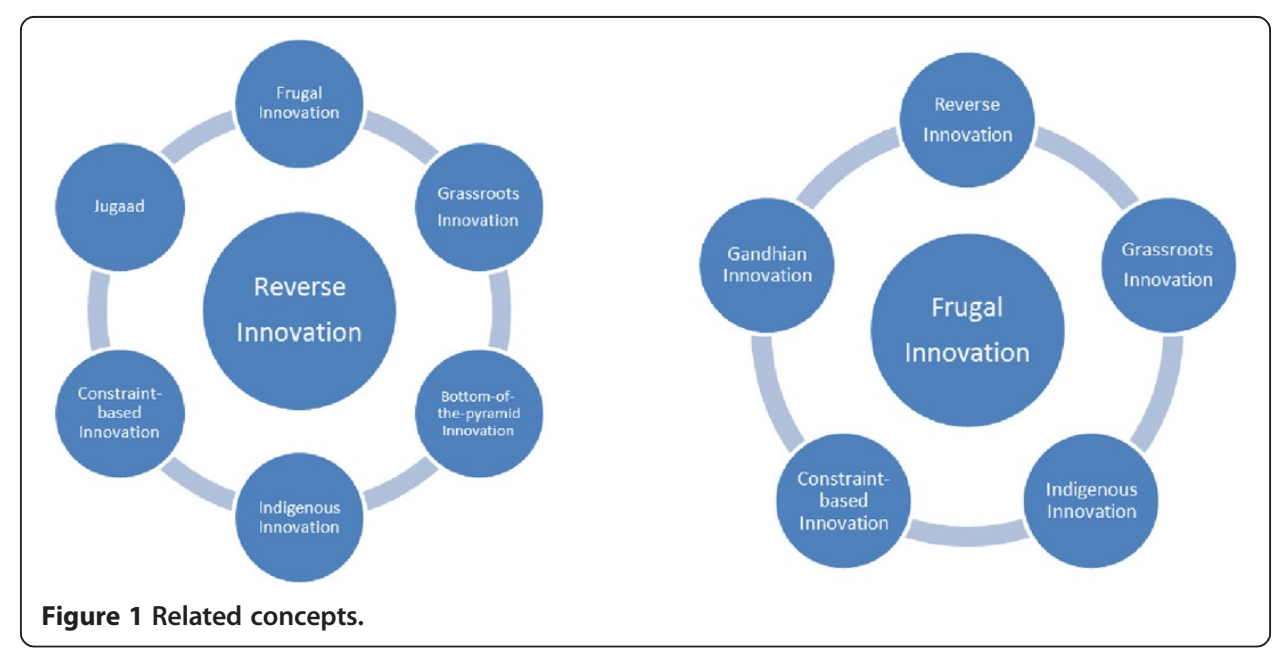


Table 1 Literature overview

\begin{tabular}{|c|c|c|c|}
\hline Hits in BSC and Google Scholar & Hits & Adjusted & Number of academic articles \\
\hline Jugaad & 77 & 68 & 20 \\
\hline Frugal innovation & 50 & 43 & 12 \\
\hline Frugal engineering & 66 & 59 & 14 \\
\hline Constraint-based innovation & 2 & 2 & 2 \\
\hline Gandhian innovation & 5 & 2 & 0 \\
\hline Grassroots innovation & 70 & 57 & 30 \\
\hline Indigenous innovation + emerging markets ${ }^{a}$ & 50 & 30 & 13 \\
\hline Catalytic innovation & 7 & 4 & 3 \\
\hline Reverse innovation & 147 & 98 & 25 \\
\hline Total & 474 & 363 & 119 \\
\hline
\end{tabular}

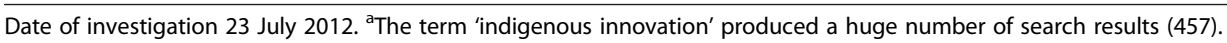
After the screening, we identified a lot of unrelated papers to our focus on product development in emerging markets. Thus, it was accompanied by the search item 'emerging markets.'

Jugaad

Jugaad has its seeds in the Indian countryside. In these rural regions, farmers build their own vehicles for daily work and for transportation of their goods. These vehicles are built using components not specially designed for vehicles but nevertheless which work well, such as a water pump used as an engine (Mitra 1995; Talukdar 2004). The users themselves usually do the inventive work. Thus, such jugaad solutions are typically based on imaginative problem solving rather than on technological inventions (e.g., Kingsnorth et al. 2011). This manner of self-help can be seen all over India, because the scarcity of all kinds of resources leads people to become self-reliant (Radjou et al. 2011).

Over time, the jugaad paradigm merged into the 'DNA' of the Indian people and became a tradition. 'Kabaad se jugaad' is a Hindi slang expression, referring to the conversion of waste (kabaad) into something useful and beautiful. As a result of jugaad, new businesses grew out of creative ideas, and inventive slum dwellers became small entrepreneurs. These businesses use an improvised approach to solve problems and satisfy needs (Saraf 2009) quickly and at a low cost (Reena 2009). Based on its improvisational background, Lacy (2011) argues that jugaad lacks taxonomy and discipline. Certainly, the jugaad approach is far from a 'process approach' in which input, conversion, output, and timeline are defined $a$ priori and product requirements are fulfilled. However, these inventions have one important feature - radical innovativeness (Prahalad and Mashelkar 2010).

The most important fact of jugaad is to start with the problem that needs to be solved - not with a product. For example, if you want to produce a refrigerator in the USA for Indian people, it will cost hundreds of dollars, and the Indian people cannot afford such an expensive machine. For them to buy it, the cost has to be less than US $\$ 75$. Thus, you cannot begin with the idea of a refrigerator; you have to begin with thinking about the customers' problem (Govindarajan 2011). This common practice in India means developing simple products with high benefits at low cost, which are (especially) designed for people at the bottom of the pyramid (BoP) (Saraf 2009). In a nutshell, jugaad is an improvisational approach to solving one's own or others' problems in a creative way, at a low cost, in a short amount of time, and without serious taxonomy or discipline. This approach, as applied by people at the BoP, makes jugaad a result of poverty and exigency. 


\section{Frugal innovation}

Due to the emerging market potential, frugal innovation - a derived management approach based on jugaad - has developed in the last decade. Gupta (2011) states that 'frugal innovation is a new management philosophy, which integrates specific needs of the BoP markets as a starting point and works backward to develop appropriate solutions that may be significantly different from existing solutions designed to address needs of upmarket segments' (p. 1). This statement describes the phenomenon in various dimensions. First, frugal innovation is basically focused on the investigation of the poor classes in (emerging) markets as target groups and as co-developers of appropriate products (Zeschky et al. 2011; Woodward 2011; Arnold and Quelsch 1998). Second, as a management philosophy, it refers to the extensive approach of adapting product management, production, and development to achieve a sufficient level of taxonomy but without high R\&D investments (Bhattacharyay 2012). Third, the resulting solutions are able to satisfy upmarket demand (Immelt et al. 2009; Lifland 2010).

Unlike Gupta (2011), many authors focus (merely) on the product perspective. With regard to frugal innovation, products typically do not have sophisticated technological features but meet customers' basic needs at a low cost by providing a comparably high value (Zeschky et al. 2011). Gupta and Wang (2009) see frugal innovation as the development of simple and ecological products, processes, services, and business models with a low input of resources, low cost, and little environmental intervention. Howard (2011) assigns similarly inherent ingenuity and a low carbon footprint. The main commonality of frugal innovations is the low-cost aspect (Hartigan 2011; Kingsnorth et al. 2011; Nunes and Breene 2011). Some authors argue that to achieve a cost advantage over existing solutions, frugal innovation goods (especially those based on Western-developed products) are stripped down to their core benefits by eliminating unessential functions to lower costs and maintain quality (Hartigan 2011; Moore 2011). Other authors like Samuelson and Scotchmer (2002) have suggested that these new products and technologies are derived using a technique called reverse engineering. Reverse engineering is the exploitation of competitors' know-how 'by starting with the known product and working backward to divine the process which aided in its development or manufacture' (U.S. Supreme Court 1974). However, as seen above, the phenomenon of frugal innovation has its starting point in jugaad. It is noteworthy that the fundamental idea of frugal innovation originates as a result from imaginative problem solving and the regional circumstances of poverty and exigency, not only for abolishing the surplus functions of sophisticated products or for investigating them. The target is to maximize value for customers and minimize inessential costs (Seghal et al. 2011, p. 35) up to 90\% price reduction compared to Western products (Gallis and Rall 2012). Seghal et al. (2011) suggest that to achieve this ambitious aim, an intrinsic cost discipline is imposed to avoid needless costs and to satisfy emerging market customers by considering their unique needs (p. 33). As Nunes and Breene (2011) note, the focus of frugal innovation is on the emerging markets only by designing products and services especially for people from the BoP whereby other concepts, such as reverse innovation, are mainly targeted to Western markets despite the fact that the products and services are designed first for emerging markets.

\section{Frugal engineering/constraint-based innovation}

Moore (2011) and Woodward et al. (2011) contend that the above explained term frugal innovation arises from the process perspective when innovation is done in a frugal way. 
However, this is known as frugal engineering or constraint-based innovation. In this context, it is considered the 'ability to absorb, adapt, and build upon the technologies imported from abroad rather than produce completely novel technologies' (Kumar 2008, p. 251) to reduce total cost, accelerate product development (Reddy 2011, p. 1), and deliver value for money (Kumar 2008, p. 254). Frugal engineering or constraint-based innovation focuses on awareness and a cognitive approach in developing new products, services, and businesses in constrictive conditions (Sharma and Gopalkrishnan 2012).

Because innovations address unique needs, the development of appropriate products under constrictive conditions requires a suitable customization of products, processes, and services as well as technology and business models, according to the environment of local customers. Prahalad (2012), Varadarajan (2011), and Sheth (2011) remind us to consider the perspicacious requirements for innovation in emerging markets, such as affordability, availability, accessibility, and usability ${ }^{c}$, as well creating customer awareness (Prahalad 2012). To meet the requirements, Prahalad (2006) advises collaborative work with both customers and civil society organizations or governments. Altman et al. (2009) refer additionally to social development players, delivery providers, and local entrepreneurs (p. 47).

Simultaneously, Moore (2011) argues that frugal innovation goes beyond R\&D by increasing the efficiency of the whole supply chain: there is no use of modern technology, no fuel, and no capital investment but a high level of service and adaptation to circumstances in the operating environment (p. 1). Moreover, Gupta and Wang (2009) highlight that 'the key to leveraging any product or service as a platform for future growth is to treat it as a bundle of capabilities instead of becoming overly constrained by its current features, branding, distribution channels, or targeted customers' (p. 12). Tata Motors, for example, is recognized for its cheap car, the Tata Nano (Tata Motors 2012). The Tata Nano costs about US\$2,500 and is used by thousands of low-income customers. In spite of the low price, the car has passed the European crash-test safety standards. The company's capabilities include insights into customer needs in low-income areas (e.g., India), proprietary technologies, a supplier network, and the internalized philosophy of frugal engineering (Gupta and Wang 2009). Hence, if DMFs want to imitate such a product (or product development), they need to extend their capabilities behind the processes, not just copy the frugal approach.

In summary, the central basis of frugal innovation is to consider emerging markets to be serious markets with potential for sales, as source of resources, and potential points of origin for goods and services demanded worldwide (Chattopadhyay and Sarkar 2011 p. 44). The products are able to move upmarket to satisfy customers' needs in developed countries as well (Hang et al. 2010, p. 26). Govindarajan (2012) states that if 'we can innovate for India we can also simultaneously innovate for the world' (p. 87). Fukuda and Watanabe (2011) designate the predominant benefit of frugal innovation as enabling a shift of emerging economies from growth driven by consumption into growth driven by investment, which is currently the significant difference between developed and developing economies (p. 91 ff.). As seen above, some EMFs are breaking this new ground yet.

\section{Gandhian innovation}

Prahalad and Mashelkar (2010) investigated how companies (in India) innovate and identified three types of what they called Gandhian innovations. The first type is the technology-driven innovation, in which EMFs take advantage of Western technology by creating new business models based on it - with an impact on the industry's dynamics 
(e.g., partitioning work in the IT sector that leads to the outsourcing of assignments from DMFs to Indian engineers or EMFs). The second type is the capability-driven innovation, which involves creating or obtaining new internal capabilities (i.e., technical expertise) to solve problems; collaborations with other companies and $R \& D$ are common practices. Tata Motors, for instance, cooperates with numerous technologically advanced companies (Bosch, Johnson Controls, Toyo, Behr, etc.) to develop the appropriate components for their $\$ 2,500$ car. The third type combines external technology with the internal capability approach by merging different standard technologies to get advanced products requiring lower production costs. For example, in 2007, Computational Research Laboratories (CRL) developed the fourth fastest computer in the world at a cost reduction of more than $20 \%$ compared to other supercomputers, by designing a holistic new design and using off-the-shelf technology (p. 135).

\section{Catalytic innovation}

A comparison of Gandhian innovation and other traditional approaches reveals the former's stronger focus on the relevance of both external and internal sources (technology, capabilities) of the developer (particularly companies). Prahalad and Mashelkar (2010) extend the Ghandian innovation approaches - focusing either on technology (products) or on processes - by pointing out the different ways of using the source's technology and capability. Further, the authors emphasize the social claim behind the phenomenon: 'Learning to do more with less for more people, we believe, should be the innovator's dream' (Prahalad and Mashelkar 2010). This is done by switching from premium pricing and abundance to affordability and sustainability to make products and services accessible to the world's populace. Christensen et al. (2006) call these novel practices 'catalytic innovations', which are based primarily on social change rather than on maintaining the status quo through the development of new products by existing players and partners (see also Munshi 2010). The social entrepreneurs engaging in catalytic innovation aspire to increase the social wealth of poor customers by creating 'scalable, sustainable, system-changing solutions' (p. 96). Five qualities are assigned to catalytic innovators: First, they push social change in a systematic way by using economies of scale and replication. Second, they fulfill needs that are served badly or not at all. Third, they offer low-cost solutions with performance that is reduced but still sufficient for customer satisfaction. Fourth, they explore unusual resources such as volunteer manpower, donations, and intellectual capital that were not considered attractive by the competition. Fifth, they are underestimated or ignored by present competitors (Christensen et al. 2006 p. 96 ff.). Considering these qualities, the analogy between catalytic innovation and frugal innovation is recognizable, but for catalytic innovations emphasis on small, unnoticed competitors and social change is added. The Grameen Bank of Bangladesh, which offers microfinance in India, is an example of catalytic innovation. The bank's microfinance business loans help small entrepreneurs at the BoP to start up their own businesses. No one intended to 'invest' in people or businesses at the BoP. Surprisingly, the default rate is below $3 \%$, which, compared to the $5 \%$ default rate of credit card issuers in the USA, turns out to be very good (Mohan and Potnis 2010).

\section{Grassroots innovation}

The consideration of businesses' social responsibility is also a significant issue in grassroots innovation, which is characterized by social integrity and poor people being 
considered inventors. The inventions are primarily designed to reduce or eliminate drudgery and are created by local people with the available resources (Gupta 2008, p. 58). Thus, grassroots innovation is similar to jugaad. However, the additional aspects of networking and ecological comprehension, as being an important factor in grassroots innovation, are missing in the concept of jugaad. Networking is important because advancing innovations at the 'grassroots level' - particularly in rural areas where science, policy, and demand hardly meet - requires intensive communication between local persons, which plays an important role in encouraging 'little science' (Gupta 1999, p. 1 ff.). In the 1990s, a social network called the Honey Bee Network was established to advance small inventions by farmers who had creatively solved local problems by creating a platform to reward their creativity and spread their knowledge through a database (Fukuda and Watanabe 2011; Gupta 1997). Furthermore, the database provides information on the availability of solutions and inventive sources across borders, including an overview of great inventors and their locations (Kastelle and Steen 2010).

Seyfang and Smith (2007) extend this concept by adding a 'green' component: '[it] describe[s] networks of activists and organizations generating novel bottom-up solutions for sustainable development and sustainable consumption; solutions that respond to the local situation and the interests and values of the communities involved. In contrast to mainstream business greening, grassroots initiatives operate in civil society arenas and involve committed activists experimenting with social innovations as well as using greener technologies' (p. 585).

As in jugaad, Seyfang and Smith's approach is driven by individuals and groups of people and is organized locally. Therefore, the coordination level is low, collaborations are based on 'social capital rather than formal organizations', research competence is application-oriented, and specialization is weak (Cooke and Memedovic 2006, p. 8). In contrast, the Honey Bee Network at least resolves the organizational gap by expanding the number of participants and improving organization using modern communication channels to transfer knowledge among local, national, and even international individuals and groups. For emerging markets, the transfer of knowledge or technology between groups/ companies/economies is the crucial point of the term discussed in the following section.

\section{Indigenous innovation}

The little research that has been undertaken on indigenous innovation focuses on the macro-economic level and addresses the inherent difficulty of increasing benefits from international trade for developing countries. In the context of international R\&D activities, indigenous innovation research considers technology transfer between enterprises in advanced and developing countries as well as the resulting effects for the domestic economies in developing countries, or spillover effects (Fu and Gong 2011; Schwaag Serger and Breidne 2007). Fu and Pietrobelli (2011) identify a congruent level of indigenous knowledge (absorptive capacity) based on local R\&D in the developing country as necessary for gaining economical benefits from foreign technology transfer. Indeed, shared R\&D activities among indigenous companies (e.g., EMFs in China) support technological advancement without serious problems; contrary to popular belief, the benefits of R\&D activities by foreign-invested enterprises are debatable. Considering indigenous innovation, $R \& D$ activities by foreign companies within emerging markets have a negative effect on technological change because of inadequate technology in the 
domestic industry and/or increased competition for limited domestic experts. However, in the second step, these foreign R\&D activities positively affect the domestic economy by increasing the inflow and diffusion of superior knowledge and technology (Fu and Gong 2011). Nonetheless, Fu and Pietrobelli (2011) consider foreign technology inflows as a complement, and not as a substitute for indigenous technology, because of its strengthening of the absorptive capacity for human capital, including the additional $R \& D$ expenditures in the emerging market. The technology transfer (or spillover effect) is only effective if there is human capital which is able to absorb the new knowledge. An investigation of the technological capabilities of developing countries revealed that indigenous EMFs are often creators of technology in several sectors. They export to middle-income countries, especially to economies with similar factor endowment and technological levels (Fu and Gong 2011). To operate in the developed world, emerging economies must change their present factor endowment by pushing their technological knowledge and capabilities. Accordingly, China's gross domestic expenditures on R\&D increased by 855\% between 1995 and 2008, whereas the R\&D expenditures in Europe increased by only 50\% (European Commission 2011, p. 45).

From the opposite perspective, DMFs are encouraged to analyze and discuss the absorptive capacity of the chosen market and the innovation capability of the local company as a partner before pushing forward to internationalize their $R \& D$. However, considering the increasing competition in emerging markets, DMFs also need to grow economically, culturally, and socially in these emerging markets to protect their positions in their home markets. Otherwise, ambitious competitors like Tatas and Mahindras will disturb their market positions in the developed world (Govindarajan 2012). Finally, indigenous innovation is the scientific reference point for discussions about different understanding of the term innovation as well (Brem 2009).

\section{Reverse innovation}

Foreign R\&D undertaken by DMFs to create frugal products for emerging markets which are also sold in developed markets is called reverse innovation (e.g., The Economist 2010b; Saraf 2009). This term is commonly used in the press (e.g., Howard 2011), but not much research has been done on this phenomenon so far - at least, not that has been published in scientific journals.

Nunes and Breene (2011) distinguish between frugal innovation and reverse innovation as follows: frugal innovation is designing offerings specifically for low-income market segments, while reverse innovation is developing and selling new products in emerging markets as a first step and then modifying these products for sale in developed countries. This distinction is important: reverse innovation is the main challenge for DMFs because of the increasing importance of $R \& D$ in developing markets, whereas competition takes place worldwide (Agarwal and Brem 2012; Singhal 2011). Therefore, the traditional value creation approach of DMFs is turned upside down, with a very high level of future competition. While the common 'glocalization' approach involves developing products centrally in developed economies for the rest of the world, reverse innovation decentralizes (at least) the product development of DMFs by settling people and resources in the local markets and giving them the responsibility of product development and sales and support (Immelt et al. 2009, p. 56 ff.). 


\section{Gaps between NPD in DMF's and the frugal approach}

Therefore, the whole product development process needs to be reconsidered from scratch, especially for DMFs (The Economist 2010a; Seghal et al. 2010). As mentioned above, the simple approach of abolishing the surplus functions of highly engineered products is insufficient - the existent capabilities of emerging market ecosystems are crucial. Trimble (2012, p. 19 ff.) identified five gaps that differentiate the conditions of the developing world from those of the developed world. First, the performance gap mentioned above is a result of the 'good-better-best' approach by DMFs. While providing the best products to solvent customers in the developed world, companies try to cut their products from best to good, or even fair, to offer them in emerging markets.

The infrastructure gap is the second pitfall: there are insufficient products and services (communication, transportation, banking, education, etc.) for the offerings that depend on this infrastructure. Accordingly, the offerings have to meet emerging market infrastructure needs through an adjustment of the innovation strategy to create appropriate products, e.g., General Electric's low-cost electrocardiogram with long battery life.

The sustainability gap deals with the opposing forces of economical success and environmental sustainability. In emerging markets in particular, the consequences of this gap are drastic and sustainable technology, such as electric mobility, is required. The next obstacle is the regulatory gap - regulation can be helpful or obstructive. On the one hand, incomplete regulations in emerging markets do not foster innovation efforts, but overregulated markets can increase prices needlessly.

The final gap is preferences. Differences in nature, climate, aliments, environment, etc. lead to divergent behaviors, habits, and preferences that have to be kept in mind. In reconsidering the gaps, the aim of Western R\&D has to be the treatment of emerging markets as unique customers with unique needs and unique full-product solutions.

These brief insights provide an overview of interesting aspects about the creation and development of new products and services for and in both emerging and developed markets. In the following chapter, we propose a conceptual framework based on the discussion in this chapter.

\section{Alignment of terms}

The following approach involves the development of a conceptual framework that explains the relationships between the terms. This analysis and development is based on the traditional scientific method of inquiry (Hempel 1965; Kuhn 1962) including three stages - theory conception and articulation, empirical testing and refinement, and theory affirmation and extension. In this paper, the focus is on theory conception and articulation to develop a conceptual framework.

\section{Methods}

The approach of MacInnis (2011, p. $137 \mathrm{ff}$.) is used to build the theory's conception and articulation. This approach includes four steps: (1) identification - exploring characters, (2) delineation - describing characters, (3) differentiation - discovering analogies and distinctions between the terms, and (4) advocating - implications for theory and practice.

In order to identify and explore essential attributes of each concept, all abovementioned academic articles (119) as well as a selection of 43 articles in press are investigated which contained detailed information of the terms supporting our delineation process of attributes. 
In this delineation process, Holsapple and Moskowitz (1980, p. 84) propose the identification of generalizations.' It involves the derivation of general categories that can be identified within specific explanations where attributes can be clearly aligned to. Subsequently, comprehensive understanding of the terms is supported by their differentiation. The differentiation is realized by establishing scales within the established categories in order to identify analogies and distinctions by classifying single terms.

Finally, results are summarized and practical implications are presented.

\section{Analysis and results}

\section{Identification: exploring attributes}

By screening the relevant publications, frequently occurring attributes stated as definition or description in the articles mentioned are examined and counted. The most mentioned attributes assigned to every term are briefly presented below.

For jugaad, because of the area of origin (rural areas of India) and its poor inhabitants (slum dwellers), the environment is defined as the BoP, where people live on a shoestring. Therefore, products have to cost less money - i.e., by dint of frugality by using limited resources and inventive problem solving with low taxonomy in a short time.

For frugal innovation, the BoP is seen as a potential market where sales might be gained and new competition arises. Products made and processes designed in other markets do not play a dominant role. The frugal innovation approach is predominantly product-oriented to cut costs for materials or processes through frugality and simplicity that includes, partially, an ecological idea.

Frugal engineering and constraint-based innovation are accomplished predominantly at the BoP, are process-oriented, and address the 'how to do' within corporate R\&D on the basis of a frugal approach. Thereby, the focus on R\&D processes leads to the effort to cut costs and increase efficiency. In exchange, appropriate internal capabilities have to be created or modified.

Gandhian innovation also focuses on the BoP, frugality, and simplicity but gives much more attention to creating and modifying internal capabilities and using external technology through technology transfer.

Grassroots innovations are similar to jugaad - they are rather problem-oriented and involve inventive problem-solving and frugal approaches - but are organized through online networks that simplify the knowledge transfer among inventors at the BoP. Furthermore, the concept comes along with ecological targets and claims social responsibility for people at the BoP.

As in grassroots innovation, catalytic innovations have a social claim, but that claim is characterized by changing existing business patterns into 'scalable, sustainable, system-changing solutions' (Christensen 2006, p. 96) for people at the BoP by using frugal approaches.

The last two terms differ a lot from the described ones. Indigenous innovation is more about how emerging markets (especially the BoP) benefit from the changing environment and increasing attention from EMFs and DMFs. Therefore, it is focused predominantly on the knowledge transfer (especially on inherent spillover effects) and creating or appropriately modifying internal capabilities.

Reverse innovation includes actions opposite to those described for the previous terms by using the BoP as source of inventive problem solving (frugal approaches) to 
satisfy local demands with locally developed products (product orientation) and searching for demand in developed markets.

The stated attributes are consolidated in Figure 2 (see below).

It is evident that a BoP focus can be observed in almost every concept described, as does a frugal approach expressed in terms of frugality, simplicity, or ecological or social aspects. However, the terms differ in terms of the orientation of problem, product, or process. Within these terms, certain delineations have to be made to gain explicit insight into their attributes.

\section{Delineation: aligning attributes}

Hereby, categories are used to reflect the real world by 'often imageable stimuli that become prototypes' (Gabora et al. 2008, p.89; Rosch 1999). Jugaad is considered as a prototype, and all related attributes are used as basic description of the phenomenon. In order to structure all attributes, categories are introduced which are able to include all accompanied attributes. It is quite important to mention that all selected categories have to be disjunct so that no attribute can be aligned to more than one category (Hsieh and Shannon 2005). The used categories are built from four key factors in new product development (NPD) which were developed by Shum and Lin (2007) who analyzed 14 benchmarks and 25 best practice studies. The key factors are market orientation, resources and stimulus, organization for collaboration and communication, as well as strategic fit and shared vision. Since jugaad is an improvisational approach, the key factors strategic fit and shared vision need to be neglected in this investigation.

In consideration of jugaad, all abovementioned attributes are listed in Table 2. Furthermore, the defined categories need to be transformed in measurable categories in order to compare further terms (frugal innovation, etc.) in regard to jugaad.

As shown in Table 2, the measurable categories are sophistication, sustainability, and emerging market orientation. The different types of innovations can be evaluated and assigned to these categories in order to differentiate them from each other.

\section{Sophistication}

The considered attributes reflect a certain object with a specific degree of sophistication and complexity. It plays a role in matters of coordination or communication as well as to achieve a minimum level of taxonomy and discipline within the terms. The sophistication of a term is evaluated by the complexity of inherent processes as well as the interaction of the categories involved (communication and coordination level).

\section{Sustainability}

The attributes involve up to two claims: social and ecological responsibility. The claims are considered equivalent. The terms investigated contain both, one, or none of these claims.

\section{Emerging market orientation}

The terms vary concerning emerging, developed, or international markets in matter of sales or supply market. 


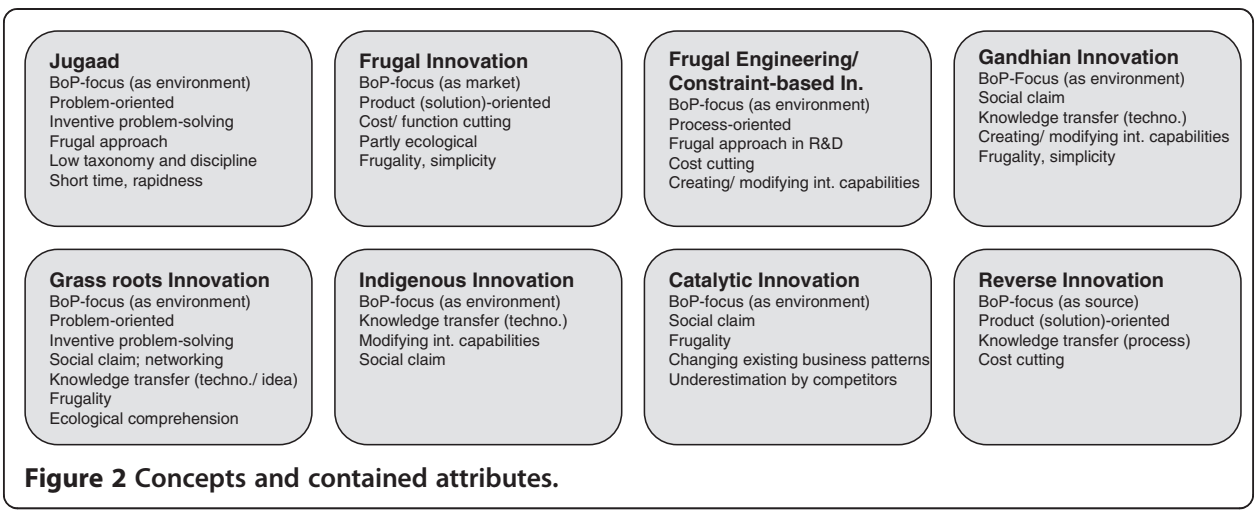

\section{Differentiation: analogies and distinctions between the terms}

The terms are classified according to the abovementioned categories to depict the analogies and distinctions between them. To classify a term as belonging to one category, the categories are graded in a qualitative scaling. Based on the scale and the included evaluation of the terms, specific tendencies and attributes of the terms are revealed.

\section{Sophistication}

In order to facilitate the evaluation, the classification for sophistication is scaled as low/ medium/high (see Figure 3). Low indicates that almost no coordination or systematic communication is accomplished for the actions involved in the terms (for example, from the description of jugaad, which is an improvised approach that lacks in taxonomy and discipline $\rightarrow$ low level). Medium demands at least a minimum level of communication between people of the same group to coordinate them and to fulfill the requirements of an action. Stated processes of the terms within literature are involved in achieving a sufficient level of taxonomy. High refers to a sophisticated level of coordination, communication, and process complexity - without the coordination of high complexity, the concept cannot be applied.

Jugaad and grassroots innovation are accomplished intuitively (or, at least, without structured processes and approaches) by giving preferential consideration to problem solutions in the direct environment (Gupta 2008; Kingsnorth et al. 2011). Because of this intuitive approach, jugaad relies on improvisation and imaginative problem solving and no stated (documented) reproducible process can be evaluated. The functional reliability of a technical solution cannot be verified because of missing processes and the lack of communication involved in the first step. Hence, jugaad is assigned a very low level of sophistication.

Grassroots innovation is similar to jugaad but involves systematized communication through networks and communities through coordinated interaction between national

Table 2 Jugaad as prototype

\begin{tabular}{|c|c|c|}
\hline Description from literature analysis & Key factor & Measureable category \\
\hline Bottom of pyramid (BoP) $\rightarrow$ emerging markets & Market orientation & Emerging market orientation \\
\hline $\begin{array}{l}\text { Inventive problem solving, low taxonomy, complexity } \\
\text { reduction, cost-effectiveness, usefulness, quick results }\end{array}$ & $\begin{array}{l}\text { Organization for collaboration } \\
\text { and communication }\end{array}$ & Sophistication \\
\hline Frugality, constrained resources, scarcity, exigency & Resources and stimulus & Sustainability \\
\hline
\end{tabular}




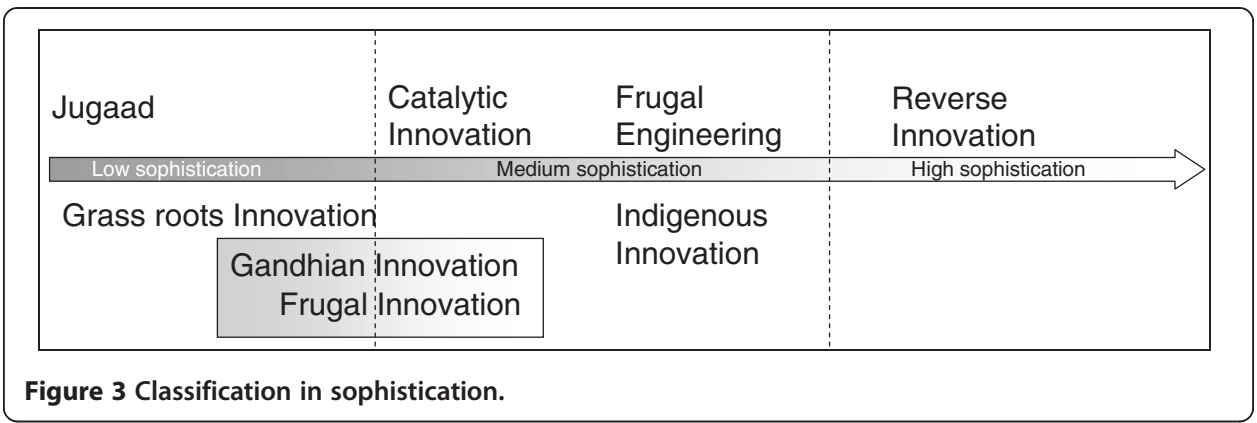

and international inventors. The means of communication in such networks can range from simple Internet blogs, where guests post their newest inventions, to sophisticated networks, where the creative work of local inventors is presented. Owing to its common appearance as a platform for simple communication, grassroots innovation is assigned to a lower level of sophistication.

Frugal engineering/constraint-based innovation and indigenous innovation focus on processes within product development, including the inherent knowledge transfer from developed to emerging markets (Kumar 2008; Moore 2011; Schwaag Serger and Breidne 2007). Indigenous innovation is centered predominantly on the spillover effects of trade and shared R\&D activities (Fu and Gong 2011), whereas frugal engineering focuses on product development in general with an eye for potential savings (operational sight) - external knowledge transfer is only one opportunity (Reddy 2011). In this vein, the complexity of inherent processes and interaction is definitely higher in indigenous innovation than in jugaad or grassroots innovation, and a mid-range level of sophistication is achieved.

Frugal innovation and Gandhian innovation involve more perspectives. Owing to the short history of frugal innovation, it cannot be assigned to any one level of sophistication. Some authors assign frugal innovation to the product perspective (Gupta 2011; Hartigan 2011; Kingsnorth et al. 2011) and others to the process perspective (Woodward 2011), while still others declare that frugal innovation comprises products, processes, and business models (Moore 2011; Prahalad 2006). Therefore, frugal innovation has low sophistication at the product perspective and is in the mid-range for the process perspective and business models.

Gandhian innovation is also novel at the product perspective (designing new products by using and transforming existing technology) and the process perspective (development by establishing R\&D networks) and establishes new business models around existing products (Prahalad and Mashelkar 2010). Hence, Gandhian innovation is assigned to low and mid-range sophistication.

Catalytic innovations exist on the product perspective (low price, lower performance), the process perspective (high scaling and replication), and in business models; involve new concepts using unusual resources; and serve new clients, e.g., as in microfinance. Therefore, catalytic innovation is predominantly assigned to the mid-range taxonomy.

Finally, reverse innovation focuses on product development (as product and process perspective) in emerging markets and a return of new products to developed markets (business model) (Immelt et al. 2009). Hence, its concept includes other terms like frugal innovation, frugal engineering, and Gandhian innovation, and it additionally turns the geographical value-added process upside down by developing products in emerging 
markets and spreading them out to the rest of the world. Because of this combination of several concepts, reverse innovation is assigned to the highest level of sophistication.

\section{Sustainability}

When considering the terms regarding sustainability, they can be divided into three levels. In the first level, the examined concept has no or little social (s) or ecological (e) sustainability. In the second level, the examined concept has one of these forms of sustainability as a central component. In the third level, the concept focuses on both social and ecological responsibility.

As shown in Figure 4, jugaad, reverse innovation, and frugal engineering (including constraint-based innovation) involve neither social nor ecological efforts as central attributes (Radjou et al. 2011; Reena 2009; Saraf 2009). These terms are focused on economical, technical, or personal processes and approaches without considering the environment in a social or ecological way (Brem and Ivens 2013).

Frugal innovation is assigned to the second level, as ecological effort is an important attribute (Gupta and Wang 2009; Howard 2011). Gandhian innovation, catalytic innovation, and indigenous innovation are all assigned to the second level because they feature social responsibility, especially in terms of emerging markets and their residents (Christensen et al. 2006; Fu and Gong 2011; Prahalad and Mashelkar 2010; Schwaag Serger and Breidne 2007). The only concept that involves both social and ecological responsibility is grassroots innovation. Seyfang and Smith (2007) in particular put a strong focus on the 'green' focus of responding to local situations, interests, and values in local communities.

\section{Emerging market orientation}

By looking at the market orientation of the types of innovation, we can infer that only some of them serve emerging markets exclusively. Therefore, a classification is accomplished by setting up three levels (see Figure 5). The first is 'emerging markets.' Here, emerging markets are treated as the target market (for NPD and sales) - jugaad, indigenous innovation, catalytic innovation, and Gandhian innovation can be assigned to this level. These terms are predominantly narrowed to emerging markets on behalf of local actors (Christensen et al. 2006; Fu and Gong 2011; Kingsnorth et al. 2011; Prahalad and Mashelkar 2010; Saraf 2009). The second level is 'international markets.' This level includes terms that serve both emerging and developed markets - either the concept originated in emerging markets but is applied in both or the BoP is the general focus without a specific sales market direction. Frugal innovation and frugal engineering are based on concepts focused on emerging markets but are also systemized by companies in developed markets. Therefore, both terms are assigned to international market orientation (Gupta 2011; Kumar 2008; Kumar and Puranam 2012; Reddy 2011; Woodward 2011). Grassroots innovation includes inventions from individuals or social groups without focusing on emerging or developed markets in particular and is assigned to international market orientation (Seghal et al. 2010).

The last level is 'developed markets.' Here, the included terms primarily serve developed markets; even if the product was dedicated to emerging markets in the first place, the current intention is to serve developed markets. Reverse innovation, for example, involves emerging markets or the BoP as sources but actually explores opportunities in 


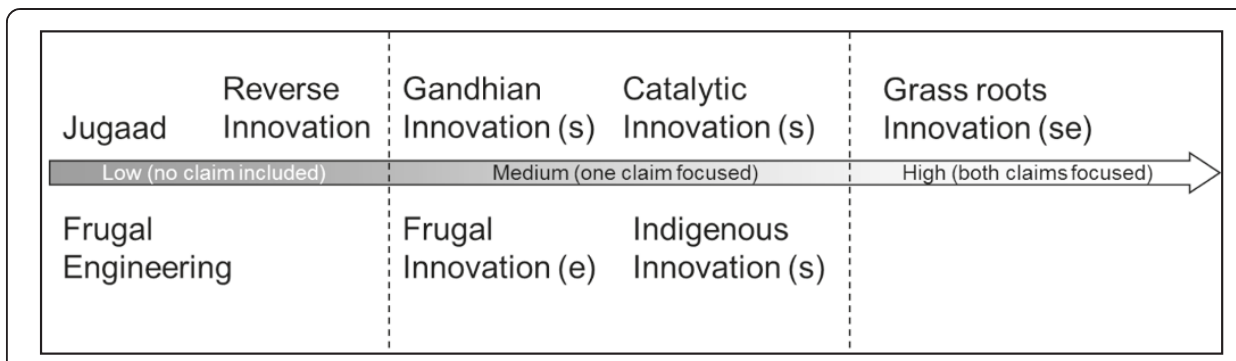

Figure 4 Classification in sustainability.

developed markets (Immelt et al. 2009). Hence, the emerging markets are not the real focus; instead, developed markets play a predominant role.

To get a more general view of the categories and the classification of the terms, all previously mentioned classifications are merged into a comprehensive multidimensional view (see Figure 6).

In Figure 6, it is shown that all three categories vary from one extreme to the other. While reverse innovation is characterized by high sophistication and low sustainable effort to serve developed markets, grassroots innovation has high sustainability and low sophistication to serve developed and emerging markets. All the terms are situated within a framework characterized by the examined categories of sophistication, sustainability, and emerging market orientation.

\section{General tendencies among terms}

Owing to the strong growth of economic power in emerging markets, all the concepts discussed involve either the attempt of EMFs to compete with DMFs in new ways or the reaction of DMFs by adapting their own R\&D to global challenges such as competition from emerging markets.

The will and ability of DMFs to open up their corporate R\&D to external sources and approaches indicate the increasing need for global $R \& D$ that (1) considers emerging markets to be equally relevant to markets in developed economies; (2) assesses these markets as development sites, rather than simply production sites and sales market; and (3) assigns $R \& D$ in emerging markets to create innovative products - that is, new products, not only adaptations - to align with existing products. This new point of view changes the approach to current global R\&D from its foundations. Even though the concepts have come to prominence only in a very limited circle of companies thus far,

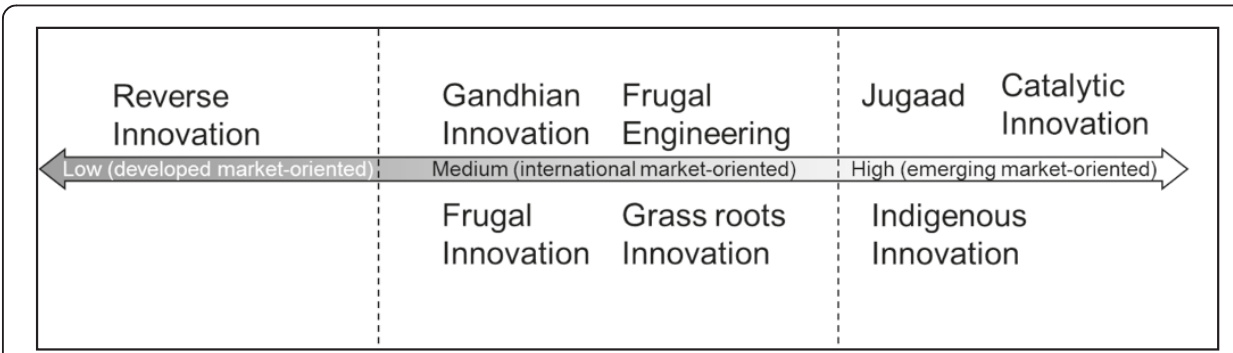

Figure 5 Emerging market orientation. 


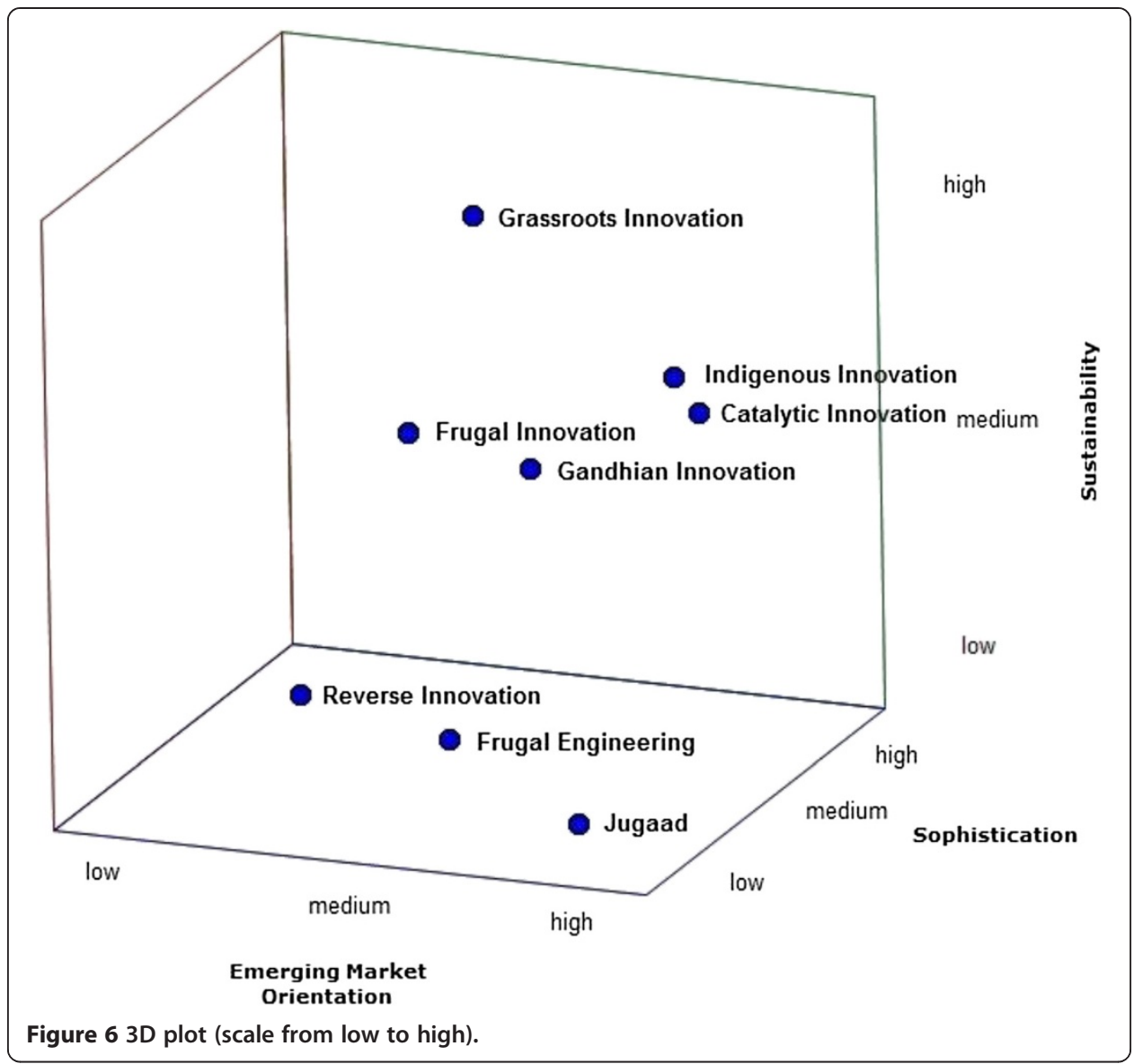

the first successes indicate the potential of successful products out of emerging markets and may spark interest in global companies.

Another important fact is that sustainability is an essential part of R\&D. Ecological impacts, social unrest owing to negligent handling of resources, and social exclusion have major effects on markets, particularly in emerging economies. In order to ease such effects, concepts such as grassroots innovation indicate the capability of corporate $R \& D$ to put sustainable development into practice, especially for people at the BoP.

\section{Implications for theory and practice}

As discussed in the literature review and the introduced investigation, the terms contain many similar and divergent attributes. On one hand, all the terms are closely connected because of their focus on the BoP. On the other hand, every term is characterized by its orientation for purpose, application area (product, process, structure, etc.), or approach (focus, taxonomy, etc.), which leads to high complexity. The missing classification of terms in the past accounts for the small amount of research done in recent years and the differentiated perceptions produced.

Now, the presented framework supports further research in new paradigms for corporate R\&D, particularly in relation to emerging markets. This framework enables scholars to compare concepts from developed and emerging markets, to address studies specifically by using consistent terms, and to advance research into the concepts according to their characterization. Especially in building theories and hypothesis, further 
research, on the basis of the delineation of presented terms, can be conducted to comprehend and discuss this matter further. In order to facilitate the future application of the terms and to build common understanding of the terms, we propose below definitions of presented and delineated terms (see Table 3).

In this vein, the investigation of the new approaches contributes to the RBV. As mentioned in the introduction, the RBV is divided into resources and capabilities where resources are the 'stock of available factors' and capabilities are the 'capacity to deploy resources [...] using organizational processes, to effect a desired end' (p.35). However, three of eight concepts remain low in taxonomy without any organizational process or systematic approach and four of eight are rather in the beginning of becoming systematic. The complex R\&D top-down approach is replaced by a simple bottom-up approach through the combination of earmarked assets. Even though that it sounds trivial, the bottom-up approach creates marketable product solutions at a low cost level that usual market participants, i.e. foreign companies, could not reach. Hence, these concepts complement the RBV by adding ecological aspects as resources, i.e., the reintegration of obsolete resources/former technologies of other companies as replacement of missing (own) resources without additional costs. Another aspect is the setting of the civil society, here people at the BoP, as strategic industry factor. In a nutshell, the new approaches complement the RBV by considering the civil society as strategic industry factor as well as using obsolete resources by dint of the reintegration which is missed in the traditional RBV.

In consideration of economic practice, the concepts behind the terms have not been applied commonly in business. In the present investigation, the terms are classified in a distinct manner, and the underlying concepts can be amplified in terms of specifications, functions, and applications. Hence, companies can more easily evaluate the benefits of the presented concepts and integrate them into their corporate environments by bringing these new concepts into agreement with their R\&D and business strategies. For instance in regard to $R \& D$ approaches, companies are asked to reflect more frequently former and obsolete product solutions from their own or other companies to gain cost-effective innovations. The lack of past reflection is already known and accomplished in few methods such as 'lesson learnt' or learning from expired patents.

\section{Limitations and further research}

This paper predominantly uses the databases in Business Source Complete for conducting analyses. Although this is a huge source of 20 databases, further sources could suggest additional views and further implications for theory and practice. Thus, further concepts (e.g., extreme affordability) that have drawn little interest from researchers in the past, but might be interesting for future research, can be found in the literature.

Furthermore, additional qualitative and quantitative research on this topic is required. The present study focuses on emerging markets from a developed market view, that is, its analysis provides a broader view on these concepts. Qualitative research such as the assessment of the cultural and behavioral aspects of actors within emerging markets and its impact on R\&D is necessary. Future research could also integrate the approaches based on the underlying phenomenon but applied differently in other countries. Finally, it is recommended to conduct quantitative studies, such as the comparison of DMFs and EMFs in terms of their R\&D performance in international markets, as well as long-term studies, 
Table 3 Proposed definitions

\begin{tabular}{|c|c|}
\hline Term & Proposed definition \\
\hline Jugaad & $\begin{array}{l}\text { An improvisational approach to solving one's own or others' problems } \\
\text { in a creative way, at a low cost, in a short amount of time, and without } \\
\text { serious taxonomy or discipline applied by people at the BoP as a result } \\
\text { of poverty and exigency }\end{array}$ \\
\hline Frugal innovation & $\begin{array}{l}\text { A derived management approach, based on jugaad, which focuses on } \\
\text { the development, production, and product management of resource- } \\
\text { saving products and services for people at the BoP by achieving a suf- } \\
\text { ficient level of taxonomy and avoiding needless costs }\end{array}$ \\
\hline $\begin{array}{l}\text { Frugal engineering/constraint-based } \\
\text { innovation }\end{array}$ & $\begin{array}{l}\text { Describes a process-oriented approach to adapt existing technologies } \\
\text { to local challenges by dint of the integration of the local society in } \\
\text { order to reduce inherent development costs and time }\end{array}$ \\
\hline Gandhian innovation & $\begin{array}{l}\text { An approach that takes advantage from the adaption of existing } \\
\text { technologies by integrating them into local context or/and establishing } \\
\text { local expertise by spillovers through collaborations in order to increase } \\
\text { social wealth of people from the BoP }\end{array}$ \\
\hline Catalytic innovation & $\begin{array}{l}\text { An approach that focuses on social change by breaking down existing } \\
\text { social and economic structures and creating new market structures } \\
\text { which involves new development approaches of systematic, } \\
\text { sustainable, and system-shifting kind }\end{array}$ \\
\hline Grassroots innovation & $\begin{array}{l}\text { Represents a bottom-up development approach that includes social } \\
\text { integrity and local civilians as inventors by connecting peoples } \\
\text { through social or technical networks in order to develop ecologically } \\
\text { and socially acceptable products and services }\end{array}$ \\
\hline Indigenous innovation & $\begin{array}{l}\text { Considers technology transfers, predominantly technology inflows, from } \\
\text { developed to emerging countries and their effects on local } \\
\text { entrepreneurs at the BoP }\end{array}$ \\
\hline Reverse innovation & $\begin{array}{l}\text { Represents the development of new products in and for emerging } \\
\text { countries by DMFs or EMF which will be introduced equally in } \\
\text { developed markets if the demand in developed markets is identified. } \\
\text { The extreme } \\
\text { case of reverse innovation is the development of new products in } \\
\text { emerging countries which are only introduced in developed markets }\end{array}$ \\
\hline
\end{tabular}

including longitudinal interviews and surveys. As the focus was on big companies, a focused research on small- and medium-sized enterprises may offer interesting insights about the usage of these terms as well.

\section{Endnotes}

${ }^{a}$ The MSCI Emerging Markets Index contains currently 21 countries: Brazil, Chile, China, Colombia, Czech Republic, Egypt, Hungary, India, Indonesia, Korea, Malaysia, Mexico, Morocco, Peru, Philippines, Poland, Russia, South Africa, Taiwan, Thailand, and Turkey (MSCI 2012).

${ }^{\mathrm{b}}$ The MSCI Developed Markets Index currently contains 24 countries: Australia, Austria, Belgium, Canada, Denmark, Finland, France, Germany, Greece, Hong Kong, Ireland, Israel, Italy, Japan, Netherlands, New Zealand, Norway, Portugal, Singapore, Spain, Sweden, Switzerland, the United Kingdom, and the United States (MSCI 2012).

${ }^{c}$ Further innovation drivers in emerging markets include an increase in DMFs establishing $R \& D$ centers, increase in the number of (social) entrepreneurs, and a legacy of legal and regulatory environment as well as policy failures, regulatory compliance, and sustainability (Varadarajan 2011). 


\section{Authors' contributions}

$A B$ and PW carried out all analysis equally as well as the elaboration of findings. Both authors read and approved the final manuscript.

\section{Acknowledgements}

We acknowledge support by Deutsche Forschungsgemeinschaft and Friedrich-Alexander-Universität ErlangenNürnberg (FAU) within the funding program 'Open Access Publishing' (http://www.ub.uni-erlangen.de/open-access/). We would like to thank the two anonymous reviewers for their valuable comments which helped to considerably improve the quality of the manuscript. Moreover, we thank Dirk Holtbrügge for his helpful comments on an earlier version of this paper.

\section{Received: 13 September 2013 Accepted: 31 March 2014}

Published: 03 Jul 2014

\section{References}

Agarwal, N, \& Brem, A. (2012). Frugal and reverse innovation-literature overview and case study insights from a German MNC in India and China. Proceedings of the 18th International Conference on Engineering, Technology and Innovation. IEEE Xplore: Munich. in print. ISBN 978-1-4673-2273-7.

Aggarwal, A. (2000). Deregulation, technology imports and in-house R\&D efforts: an analysis of the Indian experience. Research Policy, 29(9), 1081-1093.

Almeida, P, \& Phene, A. (2004). Subsidiaries and knowledge creation: the influence of the MNC and host country of innovation. Strategic Management Journal, 25, 847-864.

Altman, DG, Rego, L, \& Ross, P. (2009). Expanding opportunity at the base of the pyramid. People \& Strategy, 32(2), 46-51.

Amit, R, \& Schoemaker, PJH. (1993). Strategic assets and organizational rent. Strategic Management Journal, 14, 33-46.

Arnold, DJ, \& Quelch, JA. (1998). New strategies in emerging markets. Sloan Management Review, 40(1), 7-20.

Bajpai, GN, \& Euchner, J. (2011). Innovation in emerging markets: an interview with G. N. Bajpai. Research Technology Management, 54(4), 12-16.

Bhattacharyay, B. (2012). Seamless sustainable transport connectivity in Asia and the Pacific: prospects and challenges. International Economics \& Economic Policy, 9(2), 147-189.

Brem, A. (2009). The term innovation and its front end-is there a specific Asian view? In P Ordóñez De Pablos \& MD Lytras (Eds.), The China information technology handbook. Heidelberg: Springer.

Brem, A. (2011). Linking innovation and entrepreneurship_literature overview and introduction of a process-oriented framework. International Journal of Entrepreneurship and Innovation Management, 14(1), 6-35.

Brem, A, \& Ivens, B. (2013). Do frugal and reverse innovation foster sustainability? Introduction of a conceptual framework. Journal of Technology Management for Growing Economies, 4(2), 31-50.

Brem, A, \& Moitra, D. (2011). Technology transfer from Europe to Asia: insights from an Indian MNC, Technology Transfer Society (T2S) (p. 2011). Augsburg: Proceedings.

Brown, JS, \& Hagel, J. (2005). Innovation blowback: disruptive management practices from Asia. McKinsey Quarterly, $1,34-45$

Business Source Complete. (2013). About the database. Retrieved from: http://support.ebsco.com/help/index.php? help_id=DB:601\#A. Accessed: 28.10.2013.

Chattopadhyay, S, \& Sarkar, AK. (2011). Market-driven innovation for rural penetration. IUP Journal of Business Strategy, $8(3), 42-52$.

Christensen, C, Scott, D, \& Erik, A. (2004). Seeing what's next. Boston: M.A, Harvard Business School Publishing Corporation.

Christensen, CM, Baumann, H, Ruggles, R, \& Sadtler, TM. (2006). Disruptive innovation for social change. Harvard Business Review, 84(12), 94-101.

Cooke, P, \& Memedovic, O. (2006). Regional innovation systems as public goods. Vienna: United Nations Industrial Development Organization.

Dawar, N. \& Chattopadhyay, A. (2002). Rethinking marketing programs for emerging markets. Long Range Planning, $35,457-474$.

Economist. (2010a). First break all the rules. The Economist, 395(8678), 6-8.

Economist. (2010b). The power to disrupt. 395(8678), 16-18.

Ernst \& Young. (2011). Middle class purchasing power set to triple by 2030 world-wide due to the rapid growth in emerging markets. US: PR Newswire. 09/2011.

European Commission. (2011). Innovation union competitiveness report 2011. Brussels: European Commission.

$\mathrm{Fu}, \mathrm{X}, \&$ Gong, Y. (2011). Indigenous and foreign innovation efforts and drivers of technological upgrading: evidence from China. In OT Coomes (Ed.), World development (39th ed., Vol. 7, pp. 1213-1225). Amsterdam: Elsevier.

Fu, X, \& Pietrobelli, C. (2011). The role of foreign technology and indigenous innovation in the emerging economies: technological change and catching-up. In OT Coomes (Ed.), World development (39th ed., Vol. 7, pp. 1204-1212). Amsterdam: Elsevier.

Fukuda, K, \& Watanabe, C. (2011). A perspective on frugality in growing economies: triggering a virtuous cycle between consumption propensity and growth. Journal of Technology and Management for Growing Economies, 2(2), 79-98.

Gabora, L, Rosch, E, \& Aerts, D. (2008). Toward an ecological theory of concepts. Ecological Psychology, 20, 84-116.

Gallis, M, \& Rall, EL. (2012). Global development cycles: redefining technological innovation cycles and their impacts within a global perspective. International Journal of Innovation \& Technology, 9(1), 1-21.

Govindarajan, V. (2011). Jugaad—a model for innovation. India Forbes Magazine. Retrieved from: http://forbesindia. com/article/defining-debates-of-2011/vijay-govindarajan-jugaad-a-model-for-innovation/25512/1. Accessed 30.03.2012.

Govindarajan, V. (2012). On the importance of emerging markets like India in fostering Innovation. In A Bhattacharyya \& J Anand (Eds.), Business Buddhas (Business Today, Vol. 2012, pp. 86-87). Accessed 02.03.2013. 
Govindarajan, V, \& Trimble, C. (2005). Organizational DNA for strategic innovation. California Management Review, 47(3), 47-76. Gupta, AK. (1997). The honey bee network: linking knowledge-rich grassroots innovations. Development, 40(4), 36-40.

Gupta, AK. (1999). Science, sustainability and social purpose: barriers to effective articulation, dialogue and utilization of formal and informal science in public policy. Havard Kennedy School. Forum of Science and Innovation for Sustainable Development. Retrieved from: http://www.hks.harvard.edu/sustsci/ists/TWAS_0202/gupta_300199.pdf: 21.05.2012.

Gupta, V. (2008). An inquiry into the characteristics of entrepreneurship in India. Journal of International Business Research, Special Issue 1, 7(S1), 53-69.

Gupta, V. (2011a). Corporate response to global financial crisis: a knowledge-based model. Global Economy Journal, $11(2), 1-15$. Special Section.

Gupta, VP. (201 1b). 'Frugal Innovation': the new masters of management. In 'Jugaad' To Frugal Innovation (Indian MBA). Retrieved from: http://www.indianmba.com/Faculty_Column/FC1283/fc1283.html. Accessed: 09.01.2011.

Gupta, AK, \& Wang, H. (2009). Getting China and India right. San Francisco: Jossey-Bass/Wiley.

Hang, CC, Chen, J, \& Subramian, AM. (2010). Developing disruptive products for emerging economies: lessons from Asian cases. Research-Technology Management, 53(4), 21-26.

Hartigan, P. (2011). Creating blueprints for business in the 21st century: social entrepreneurship shows the way. In A Lopes-Claros (Ed.), The innovation for development report 2010-2011-innovation as a driver of productivity and economic. Basingstoke: Palgrave Macmillan.

Hempel, CG. (1965). Aspects of scientific explanation. New York: The Free Press.

Holsapple, CW, \& Moskowitz, H. (1980). A conceptual framework for studying complex decision processes. Policy Science, 12(1), 83-104.

Howard, M. (2011). Will frugal innovation challenge the west? Market Leader Quarter, 3, 53.

Hsieh, HF, \& Shannon, SE. (2005). Three approaches to qualitative content analysis. Qualitative Health Research, 15(9), 1277-1288

Immelt, J, Govindarajan, V, \& Trimble, C. (2009). How GE is disrupting itself. Harvard Business Review, 10, 56-65.

International Monetary Fund. (2012). World Economic Outlook Databases. September 2011. Retrieved from: http://www. imf.org/external/pubs/ft/weo/2011/02/weodata/download.aspx.

Jiatao, L, \& Rajiv, KK. (2009). Developing new innovation models: shifts in the innovation landscapes in emerging economies and implications for global R\&D management. Journal of International Management, 15(3), 328-339.

Kastelle, T, \& Steen, J. (2010). Grassroots innovation. Innovation Leadership Network. Retrieved from: http://timkastelle.org/ blog/2010/05/grassroots-innovation/.

Kingsnorth, AN, Tongaomkar, RR, \& Awojobi, OA. (2011). Commentary on: low-cost mesh for inguinal hernia repair in resource-limited settings. In Hernia Online FirstTM (15th ed., pp. 15-18). Retrieved from: http://www.springerlink. com/content/fr83v0v352627617/. Accessed 14.10.2012.

Kuhn, TS. (1962). The structure of scientific revolutions. Chicago: The University of Chicago Press. 2(2), 1-210. enlarged.

Kumar, N. (2008). Internationalization of Indian enterprises: patterns, strategies, ownership advantages, and implications. Asian Economic Policy Review, 3, 242-261.

Kumar, N, \& Puranam, P. (2012). Frugal Engineering: an Emerging Innovation Paradigm. Ivey Business Journal, 76(2), 14-16.

Lacy, S. (2011). Brilliant, crazy, cocky (How the top 1\% of entrepreneurs profit from global chaos). Hoboken/ New Jersey: John Wiley \& Sons.

London, T, \& Hard, S. (2004). Reinventing strategies for emerging markets: beyond the transnational model. Journal of International Business Studies, 35(4), 49-63.

MacInnis, D. (2011). A framework for conceptual contributions in marketing. Journal of Marketing, 75(July 2011), 136-154.

Mitra, BS. (1995). India's 'informal' car. Asian Wall Street Journal, 225(21), 18.

Mohan, L, \& Potnis, D. (2010). Catalytic innovation in microfinance for inclusive growth: insights from SKS microfinance. Journal of Asia-Pacific Business, 11(3), 218-239.

Moore, K. (2011). The emergent way: how to achieve meaningful growth in an era of flat growth. Ivey Business Journal, $75(6), 1-3$.

Morgan Stanley Capital International (MSCI). (2012). Country membership for the MSCl Global Equity Indices. Retrieved from: http://www.msci.com/products/indices/tools/index.html\#DM. Accessed 12.01.2013.

Munshi, NV. (2010). Value creation, social innovation, and entrepreneurship in global economies. Journal of Asia Pacific Business, 11(3), 160-165.

Nunes, PF, \& Breene, TS. (2011). Jumping the S-curve: how to beat the growth cycle, get on top, and stay there. Harvard: Harvard Business Review Press.

Petrick, IJ. (2011). Innovation in emerging markets. Research Technology Management, 54(4), 8-9.

Prahalad, CK. (2006). The fortune at the bottom of the pyramid - eradicating poverty through profits. San Diego: Pearson Education Ltd.

Prahalad, CK. (2012). Bottom of the pyramid as a source of breakthrough innovations. Journal of Product Innovation Management, 29(1), 6-12.

Prahalad, CK, \& Mashelkar, RA. (2010). Innovation's holy grail. Havard Business Review, 2010, 132-143.

Radjou, N, Prabhu, J, \& Ahuja, S. (2011). Use jugaad to innovate faster, cheaper, better. Harvard Business Review. Retrieved from: http://blogs.hbr.org/cs/2011/12/think_like_an_indian_entrepren.html. Accessed 12.03.2012.

Ray, PK, \& Ray, S. (2010). Resource-constrained innovation for emerging economies: the case of the Indian telecommunications industry. IEEE Transaction on Engineering Management, 57(1), 144-156.

Reddy, M. (2011). Indo-US trade: co-creating value. The Indian Journal of Management, 4(1), 1-2.

Reena, J. (2009). India's next global export: innovation (pp. 13-13). www.BusinessWeek.com, 12/3/2009 Accessed 20.03.2012.

Rosch, E. (1999). Reclaiming concepts. Journal of Consciousness Studies, 6, 61-78.

Samuelson, P, \& Scotchmer, S. (2002). The law and economics of reverse engineering. The Yale Law Journal, 111(7), 1575-1663.

Saraf, D. (2009). India's indigenous genius: Jugaad. The Wall Street Journal. Retrieved from: http://online.wsj.com/article/ SB124745880685131765.html, Accessed 13 July 2009. 
Schwaag Serger, S, \& Breidne, M. (2007). China's fifteen-year plan for science and technology: an assessment. In C Fair \& MW Frazier (Eds.), Asia Policy No. 4. Accessed 20.03.2012.

Seghal, V, Dehoff, K, \& Panneer, G. (2010). The importance of frugal engineering. Strategy + Business, 59.

Seghal, V, Dehoff, K, \& Panneer, G. (2011). Frugal engineering—back to basics. Market Leader Quarter, 1, 33-37.

Seyfang, G, \& Smith, A. (2007). Grassroots innovations for sustainable development: towards a new research and policy agenda. Environmental Politics, 16(4), 584-603.

Sharma, A, \& Gopalkrishnan, R. (2012). Resource-constrained product development: implications for green marketing and green supply chains. Industrial Marketing Management, 41(4), 599-608.

Sheth, JN. (2011). Impact of emerging markets on marketing: rethinking existing perspectives and practices. Journal of Marketing, 75(4), 166-182.

Shum, P, \& Lin, G. (2007). A world class new product development best practice model. International Journal of Production Research, 45(7), 1609-1629.

Singhal, V. (2011). The impact of emerging economies innovative new models of global growth and vitality are emerging. Visions, 35(2), 12-14.

Suddaby, R. (2010). Construct clarity in theories of management and organization. Academy of Management Review, 35(3), 346-357.

Talukdar, S. (2004). Makeshift miracles: the Indian genius for Jugaad. Times of India January 1st. Accessed 20.03.2012.

Tata Motors. (2012). The nano story. Retrieved from: http://tatanano.inservices.tatamotors.com/tatamotors/ nano_story_flash.html?keepThis=true\&TB_iframe=true\&height $=595 \&$ width $=820$.

Trimble, C. (2012). Reverse innovation and the emerging-market growth imperative. Ivey Business Journal, 76(2), 19-21.

U.S. Supreme Court. (1974). Kewanee Oil Co.v. Bicron Corp., 416 U. S. 470. Retrieved from: http://caselaw.lp.findlaw.com/ scripts/getcase.pl?navby=case\&court=us\&vol=416\&invol=470\#f6. Accessed: 13.04.2012.

Sauvant, KP. (2005). World investment report-transnational corporations and the internationalization of R \& D. Herndon.

Varadarajan, R. (2011)). Conjectures on innovation drivers in an emerging market: India. In DG Subhash Jain (Ed.), Handbook of research in international marketing (pp. 117-134). Cheltenham Glos (UK): Edward Elgar Publishing.

Woodward, D. (2011). Plain and simple. Director Magazin. Retrieved from: http://www.director.co.uk/ONLINE/2011/ 08_11_frugal-innovation.html. Accessed 12.03.2012.

Zeschky, M, Widenmayer, B, \& Gassmann, O. (2011). Frugal innovation in emerging markets: the case of Mettler Toledo. Research Technology Management, 54(4), 38-45.

10.1186/2192-5372-3-9

Cite this article as: Brem and Wolfram: Research and development from the bottom

up - introduction of terminologies for new product development in emerging markets. Journal of Innovation and Entrepreneurship 2014, 3:9

\section{Submit your manuscript to a SpringerOpen ${ }^{\circ}$ journal and benefit from:}

- Convenient online submission

- Rigorous peer review

- Immediate publication on acceptance

- Open access: articles freely available online

- High visibility within the field

- Retaining the copyright to your article

Submit your next manuscript at $\boldsymbol{\nabla}$ springeropen.com 